\title{
State Funeral
}

\author{
Sergei Loznitsa, 2019 \\ Screenwriter: Sergei Loznitsa \\ Place: Netherlands, Lithuania \\ Studio: Atoms \& Void \\ Length: 135 minutes \\ Language: Russian
}

\section{Kieran Wakeley, University College London}

\section{"Stalin is dead - long live Stalin."}

A sobering and, at times, perplexing meditation on a nation enthralled to the power of its most brutal leader, Sergei Loznitsa presents a reconstructed epic eulogy to the former Soviet dictator in State Funeral. Following from his previous archival documentaries, The Trial (2018) and The Event (2015), the Ukrainian filmmaker and documentarian returns to the complexities and contradictions of Soviet Russia with this haunting assemblage of restored archival footage. Originally shot by a team of over 200 camera operators, and directed by Russia's cinematic luminaries Ilya Kopalin, Grigori Alexandrov, and Sergei Gerasimov, the footage had been intended for an unreleased official state film, The Great Farewell, but was indefinitely shelved in the months following the funeral. Cut down from some 40 hours of raw footage and arranged by editor and long-time collaborator Daniellus Kokanauskis, most of the footage is being seen for the first time in nearly seventy years.

Following the announcement of Stalin's death, the film observes in comprehensive detail the public mourning across the Soviet Union. Seemingly endless processions shuffle through cordoned off Moscow streets to observe Stalin lying in state, while a forest of wreaths is laid encircling the walls of the Kremlin. Across various cities, we see mourners gather at the bases of colossal statues of Stalin, removing their caps as they pay their respects. The shots of these giant statues act as a perfect visual metaphor for the enormity of Stalin's presence in the Soviet landscape. Sombre loudspeaker announcements taken from the Russian State Archive of Sound Recordings act as a substitute for narration, describing the events and offering praise for the deceased in predictably grandiose platitudes.

In his choice to focus again and again on the procession of faces that transit through the Pillar Hall of the House of Unions, Loznitsa hints at an ambiguity in the figure of Stalin. Watching the repetitive scenes of teeming crowds processing in metered grieving, it is impossible not to question the legitimacy of this display. Is what we are seeing genuine, performative, even coerced? Is the eerie solemnity expressing grief, morbid curiosity, or a need to observe and 
contemplate during a moment of collective national trauma? Quite possibly a mixture; there is a suggestion that more is happening here than meets the eye.

This ambiguity appears to be key to Loznitsa's filmmaking process. In a recent interview with Screen Daily he stated that "I don't take sides in my film, I don't offer any interpretation. I present events chronologically and allow the audience to work out what happened." Indeed, rather than passing judgement through a particular editorial suture, or superimposing a critical narrative voice over the images, Loznitsa instead allows the footage, in its staged and polished repetition, to impart an impression of Stalinist supremacy. This unobtrusive approach is moderated by the matter-of-fact epilogue detailing the numerous human rights violations, detentions, and mass murders that occurred under the Stalinist regime. It is doubtful that these details would have been present had The Great Farewell been released as originally intended. Here, they alter the function of the propaganda as an exaltation of the deceased leader, and instead, quantify the footage as a requiem for the Russian people under Stalin's rule.

Loznitsa leaves the audience to contemplate the scale and spectacle of this mediated observance in its raw form, and to question how national imagination and collective memory have been used to shape our perceptions of the past. Speaking with fellow documentary filmmaker Pietro Marcello for MUBI, Loznitsa offers his opinion that "Stalin is allegorical for these people." ${ }^{2}$ This becomes apparent throughout the film by the omnipresent Stalinist iconography. In nearly every scene there is some representation of Stalin, whether it be paintings and banners carried by the crowds, state portraits, or statues. Stalin appears to be something beyond a national figure, he exists as the totality of the Soviet experience, the ubiquity of his singular image among the countless millions of anonymous faces substituting for a collective identity. Yet despite leaving a supposedly indelible impression on the Russian people, with Khrushchev's ascendency to First Secretary of the Central Committee, the process of de-Stalinisation and national reconciliation was swift. Within three years Khrushchev had delivered his "Secret Speech" denouncing Stalinism and the cult of personality to the $20^{\text {th }}$ Congress of the Communist Party, and by 1961, Stalin's Body had been removed from the Lenin Mausoleum.

What remains in Loznitsa's assemblage is a reliquary, cast in the image of the dictator, a memorial to the palpable, quasi-mystical power he was able to conjure. It is clear from the footage that even in death he remained a persistent presence, looming large over a nation at the precipice of an uncertain future. Though the mortal Stalin has departed, his figure with all its terrible potency remains, as Loznitsa himself remarks; despite his absence "all this space continues to revolve around him."3

\footnotetext{
1 Jonathan Romney, 'Cannes Regular Sergei Loznitsa on his Archive Documentary ‘Babi Yar. Context', Screen Daily, 10 July 2021, <https://www.screendaily.com/features/cannes-regular-sergei-loznitsa-on-his-archivedocumentary-babi-yar-context/5161450.article> [accessed 27 July 2021]

2 Pietro Marcello, 'State Funeral: Q\&A with Sergei Loznitsa \& Pietro Marcello', video clip, MUBI, <https://mubi.com/films/state-funeral> [accessed 27 July 2021]

3 Ibid.
} 